\title{
Tribological properties of plasma and HVOF sprayed composite coatings
}

\author{
Trybologiczne właściwości powłok kompozytowych \\ natryskanych plazmowo i HVOF
}

\section{Abstract}

This paper presents the properties of plasma and HVOF thermally sprayed coatings obtained by blending the $\mathrm{NiCrBSi}$ and $\mathrm{Fe}_{2} \mathrm{O}_{3}$ powders. The deposition was performed by means of the Plancer PN-120 and the Diamond Jet guns for plasma spraying and HVOF spraying, respectively. The SEM (EDS) and XRD methods were employed to study the microstructure and phase composition of the produced coatings. Although the blended powders differ in particle size, shape, and distribution, it is possible to obtain composite coatings with an $\mathrm{NiCrBSi}$ matrix containing iron oxides. Except for a different microstructure, plasma and HVOF coatings have a different phase composition, which was examined using the Bruker D-8 Advance diffractometer. Studies of the coatings wear and scuffing resistance showed that an optimal content of $\mathrm{Fe}_{2} \mathrm{O}_{3}$ is about $26 \%$ for plasma sprayed coatings and $22,5 \%$ for HVOF deposited coatings.

\section{Introduction}

Nowadays most machines require applying liquid lubricants on interacting surfaces, which allows us to achieve extremely favorable operating conditions in a friction pair. This assures long life and reliability of machine parts. In the automotive industry, for example, the demand to produce vehicles with smaller weight, that can drive at higher speeds, and can carry a higher load, has forced to develop coatings with enhancement damage tolerance and improved temperature capabilities. Today, applications of the variety of surface engine technologies and resulting coatings or surface

Dr inż. Wojciech Żórawski - Politechnika Świętokrzyska, Kielce, prof. Otakar Bokuvka - University of Zilina, Słowacja, prof. Stanisław Skrzypek AGH Akademia Górniczo-Hutnicza w Krakowie.

\section{Streszczenie}

W pracy przedstawiono właściwości natryskanych plazmowo i HVOF powłok otrzymanych w wyniku wymieszania proszków NiCrBSi i $\mathrm{Fe}_{2} \mathrm{O}_{3}$. Natryskiwanie przeprowadzono w za pomocą plazmotronu Plancer PN-120 i systemu do natryskiwania naddźwiekowego Diamond Jet. Badania mikrostruktury i składu fazowego natryskanych powłok przeprowadzono wykorzystując SEM (EDS) i XRD. Wyniki ujawniły, że pomimo znacznych różnic wielkości, kształtu i rozkładu granulometrycznego proszków, możliwe jest uzyskanie powłok kompozytowych na osnowie NiCrBSi zawierających tlenki żelaza. Stosując dyfraktometr Bruker D-8 Advance, wykazano, że oprócz różnic mikrostrukturalnych, powłoki mają również odmienny skład fazowy. Badania zużycia powłok i ich odporności na zatarcie wykazały, że optymalna zawartość $\mathrm{Fe}_{2} \mathrm{O}_{3}$ wynosi ok. $26 \%$ dla powłok natryskiwanych plazmowo i $22,5 \%$ dla HVOF.

modification let to obtain significant effects in the reliability, functionality and safety of vehicles. Particularly, surface enhancement engineering solutions which lead to reduction of wear, friction and corrosion are particularly in the area of interesting of automotive industry. The main surface engineering technologies involve; Physical Vapor Deposition (PVD), Chemical Vapor Deposition (CVD), thermochemical heat treatment, hard chromium plating and thermal spraying $[1 \div 3]$. Higher efficiency is obtained by using coatings which can fulfill different role as schematically is shown in Fig. 1. Today, different thermal spray coatings are widely applied in automotive industry. Molybdenum coatings deposited by wire flame spraying are used for transmission parts as shift forks and synchronizing rings to ensure low coefficient of friction and prevent occurring of scuffing. Piston rings, depend on the type of engine (gasoline or diesel), are sprayed with pure molybdenum, molybdenum with addition silicon, nickel or chromium 


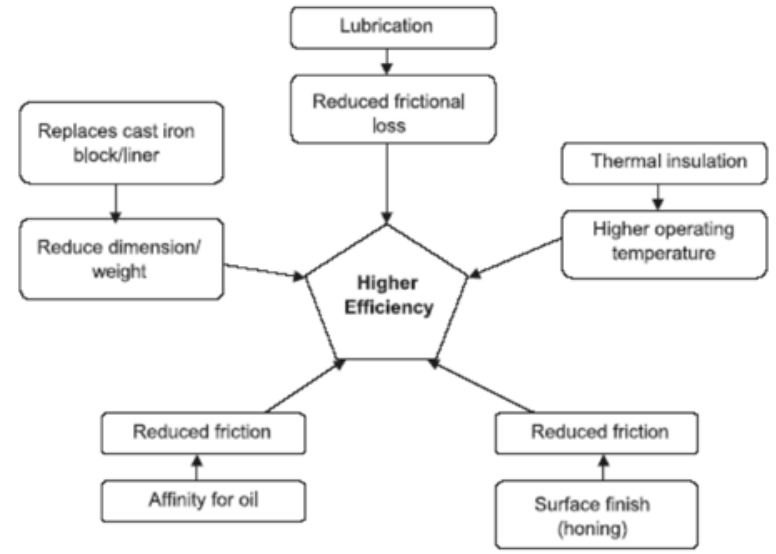

Fig. 1. Role of coating in improving efficiency of engine [1] Rys. 1. Wpływ powłok na poprawę sprawności silnika [1]

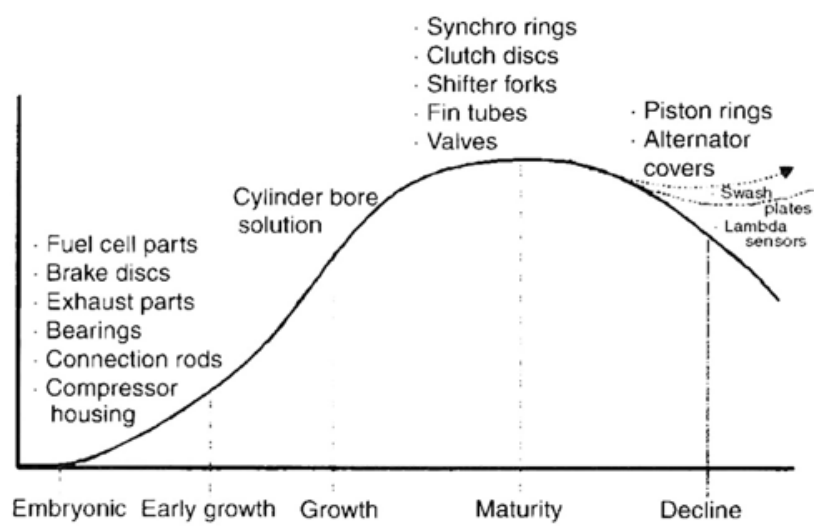

Fig. 2. Current and potential application areas for thermal spray coatings in the automotive industry [7]

Rys. 2. Obecne i przyszłe obszary zastosowania powłok natryskiwanych cieplnie w przemyśle samochodowym [7]

with flame, plasma or supersonic (HVOF) technique. Molybdenum trioxide has a lubricious properties what is essential quality in such layers. Coatings containing metal matrix carbides are also applied on piston rings $[4,5]$. For nearly last 20 years, coatings for cylinder bores of aluminum cast engine blocks were under intensive investigations. Traditionally manufactured engine blocks have been made of cast iron due to its good machinability, wear resistance and vibration damping, however weight of block was significant disadvantage. The main loadings of the cylinder bore includes rapid temperature cycling, extreme pressure, repeated shear loading and impingement of hot gases what is difficult to withstand by aluminum alloys. Separate cylinder sleeve in aluminum block made of steel or cast iron is complicated and costly solution. Moreover, due to improve heat transfer and further save of weight, reduce of the thickness of cylinder lining is necessary. Every additional millimeter of steel or cast iron lining cause increase of overall weight of engine and fuel consumption. So, the only justified solution for cylinder bore was thermally sprayed coating. Despite saving of weight, such coatings, with particular surface geometry, allow to obtain significant lower friction of the piston group what leads to fuel reduction of $2 \div 3 \%$ and decreasing of oil consumption by factor $2 \div 3[6 \div 8]$. Figure 2 presents current and potential area of applications of thermal spray coatings in automotive industry.

Adding a solid lubricant to a thermally sprayed coating causes a decrease in the coefficient of friction. The presence of $\mathrm{Fe}_{2} \mathrm{O}_{3}$ improves tribological properties of a composite coating, however, its properties are not well known $[9,10]$. The aim of this work is to study the microstructure and coefficient of friction of plasma and HVOF thermally sprayed composite coatings with an $\mathrm{NiCrBSi}$ matrix and $\mathrm{Fe}_{2} \mathrm{O}_{3}$ as a solid lubricant.

\section{Experiment}

In this study, a mixture of two powders was applied as the feedstock. The mixture consisted of $\mathrm{NiCrBSi}$ powder produced by AMIL GmbH denoted by 1060.0 used as the matrix and $\mathrm{Fe}_{2} \mathrm{O}_{3}$ powder normally used as a chemical reagent. The examination of the particle size distribution was carried out by means of a Sympatec GmbH HELOS laser analyzer. The plasma spray process was conducted with a Plancer PN-120 gun. The HVOF thermal spray process was performed using a Sulcer Metco Diamond Jet gun supplied with propane and oxygen. The plasma and HVOF spray parameters are given in Table I and Table II respectively. For the metallographic examination, the coatings were deposited on thin flat low-carbon steel samples with dimensions of $50 \times 25 \times 5 \mathrm{~mm}$, whereas for the tribological test the coatings were deposited on ring-shaped low-carbon steel samples with dimensions of $ø 35 \times 9 \mathrm{~mm}$ and faces of cylindrical samples $ø 12.7 \times 10 \mathrm{~mm}$ made of C45steel Before the spray, the substrate had to be degreased and grit blasted with electrocorundum EB-12 at a pressure of $0.5 \mathrm{MPa}$. The thickness of the coatings after grinding was $0.3 \mathrm{~mm}$.

The structure and the chemical composition of the coatings were analyzed by means of a JSM-5400 scanning microscope equipped with an ISIS 300 Oxford (EDS) microprobe. The phase composition of the powders and the coatings was determined with

Table I. Plasma spraying parameters

Tablica I. Parametry natryskiwania plazmowego

\begin{tabular}{|c|c|}
\hline Parameter & Value \\
\hline Current, $\mathrm{A}$ & 550 \\
\hline Voltage, $\mathrm{V}$ & 55 \\
\hline Plasma gas pressure, $\mathrm{MPa}$ & 0,7 \\
\hline Spraying distance, $\mathrm{mm}$ & 100 \\
\hline Powder feeding rate, $\mathrm{g} / \mathrm{min}$ & 28 \\
\hline
\end{tabular}

Table II. HVOF spraying parameters

Tablica II. Parametry natryskiwania HVOF

\begin{tabular}{|c|c|}
\hline Parameter & Value \\
\hline Oxygen flow, NI/min & 265 \\
\hline Propane flow, NI/min & 74 \\
\hline Air flow, NI/min & 374 \\
\hline Spraying distance, $\mathrm{mm}$ & 150 \\
\hline Powder feeding rate, $\mathrm{g} / \mathrm{min}$ & 94 \\
\hline
\end{tabular}


a Bruker D-8 Advance diffractometer with Co-Ka $(\lambda=1.78897 \AA)$ radiation.

A T-05 M block-on-ring type tester was used to determine the wear of plasma- and HVOF-sprayed Ni$\mathrm{CrBSi}$ and $\mathrm{Fe}_{2} \mathrm{O}_{3}$ coatings. The block, made of steel $\mathrm{C} 45$, had a dimensions $15.75 \times 10 \times 6.35 \mathrm{~mm}$. The testing involved applying a computer to aid in registering and controlling the action of the friction force in the function of time. The parameters for the T-05 tester were as follows: load $Q=4.9 \mathrm{~N}$, rotation of the ring $\mathrm{n}=32 \mathrm{rpm}$, test duration $\mathrm{t}=1 \mathrm{~h}$.

Scuffing resistance of thermally sprayed coatings under dry friction conditions was checked on a tribological tester, T-09 type Falex, which has a friction pair with a pin and vee block association. In this test, the sample in the form of a cylinder $6.3 \mathrm{~mm}$ in diameter $x 32 \mathrm{~mm}$ in length is attached to the main drive shaft by means of a shear pin and two jaws having a $900 \mathrm{~V}$ - notch fit into the holes in the lever arms. During testing, the jaws are clamped around the test piece which is rotated at 290 r.p.m. while the load exerted by the jaws is gradually increased. Test pieces with poor scuffing resistance seize at relatively low loads, whereas scuff-resistant surfaces permit much higher loads to be withstood before failure. In the present investigation, the load and the friction force were measured using load cells, and the data were monitored continuously and proceeded by a computer interfaced to the machine. Load vs. time and friction force vs. time plots were recorded during each test. As a result, the value of friction force is known. What is more, we obtain the highest value of the sample load, if no scuffing is observed.

Microhardness measurements, HV0.5, were conducted using a Zwick 3210 tester as the average of 10 measurements. The roughness of coatings after polishing was analyzed by means of a Talysurf 4 device with SUFORM program.

\section{Results and discussion}

\section{Characterization of the $\mathrm{NiCrBSi}$ and $\mathrm{Fe}_{2} \mathrm{O}_{3}$ powders}

The NiCrBSi powder possessed the following chemical composition (\%): $\mathrm{Ni}-70.51, \mathrm{Cr}-17.8, \mathrm{~B}-3.1$, $\mathrm{Si}-4.2, \mathrm{Fe}-3.4, \mathrm{C}-0.85, \mathrm{O}_{2}-0.14$. From Fig. 3a it can be seen that the particles are spherically shaped, which is characteristic of highly alloyed nickel based powders to be obtained by a gaseous spray method. Coatings produced from powders with such chemistry by remelting or plasma or HVOF thermal spray possess high resistance to wear, hence their wide application. NiCrBSi powders are deposited separately or as ingredients of blends. The presence of boron and carbon improves coating hardness, and this results from the formation of chromium, boron or iron carbides, as well as hard metallic compounds of boron and chromium in the alloy.
In $\mathrm{NiCrBSi} / \mathrm{Fe}_{2} \mathrm{O}_{3}$ composite coatings, iron oxide becomes the lubricant, as it possesses the desired properties i.e. a hexagonal crystal structure. For the testing purposes, we employed purified iron oxide with tiny, flaky, yet enhanced particles, which is normally used as a chemical reagent (Fig. 3b). The structure promotes agglomeration of particles, which makes it difficult to feed the powder to a spray gun.

The examination of the particle size distribution was carried out by means of a Sympatec $\mathrm{GmbH} \mathrm{HE}-$ LOS laser analyzer (Figs. 4a, 4b). The curves of the cumulated distribution and relative particle size distribution for the NiCrBSi powder (Fig. 4a) show that it is a powder with a narrow range of particle sizes applied in thermal spray. The experimental data concerning the particle size distribution obtained for the AMI 1060.0 powder coincided with the specifications provided by the producer, with the size ranging -25 $+5 \mathrm{~mm}$. Since the powder contains $1.91 \%$ of particles greater than $30 \mathrm{~mm}$ and $4.33 \%$ of particles less than $7.5 \mathrm{~mm}$, the range of particle sizes must be

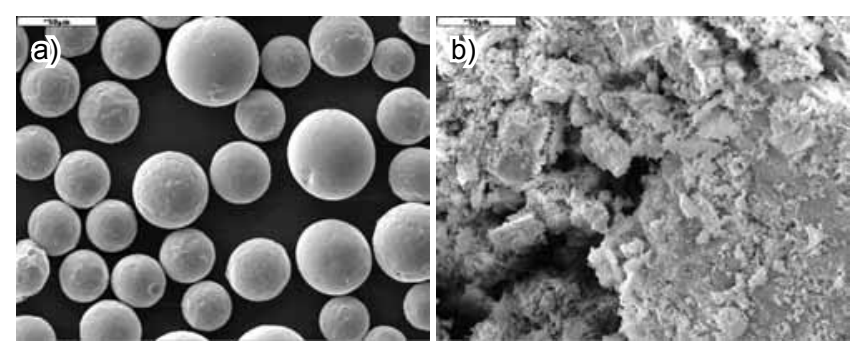

Fig. 3. Morphology of grains: a) NiCrBSi, b) $\mathrm{Fe}_{2} \mathrm{O}_{3}$ Rys. 3. Morfologia ziarn: a) $\mathrm{NiCrBSi}$, b) $\mathrm{Fe}_{2} \mathrm{O}_{3}$
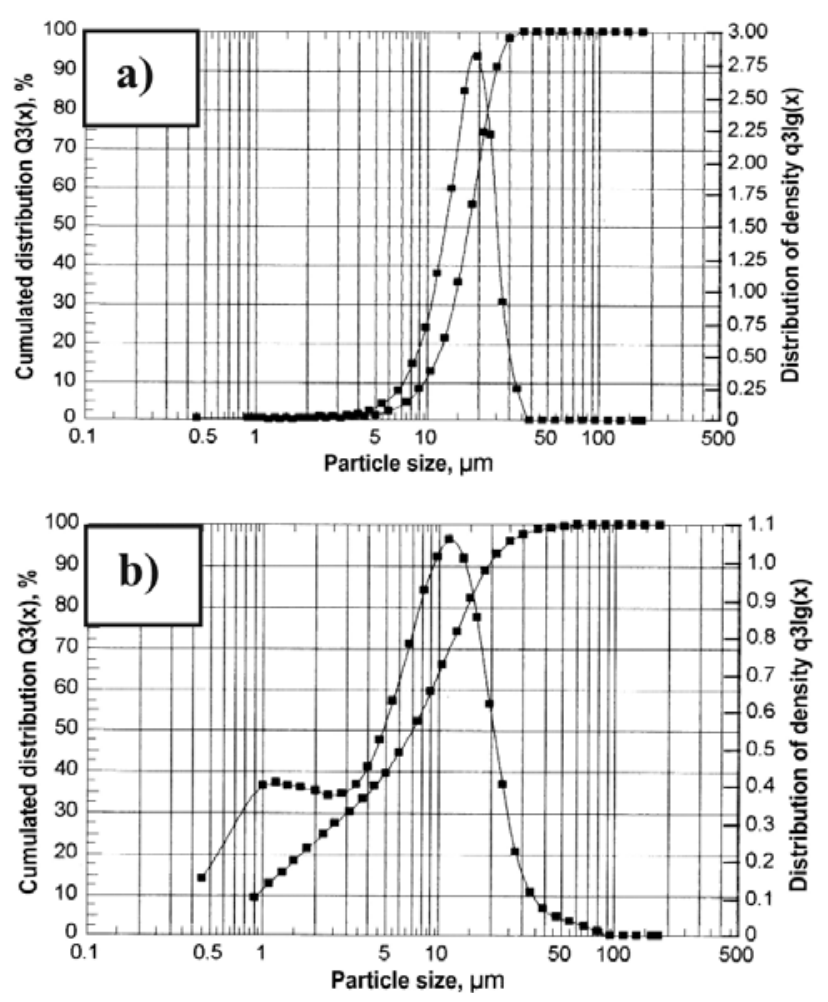

Fig. 4. Particle size distribution: a) NiCrBSi, b) $\mathrm{Fe}_{2} \mathrm{O}_{3}$ Rys. 4. Rozkład wielkości cząsteczek: a) NiCrBSi, b) $\mathrm{Fe}_{2} \mathrm{O}_{3}$ 


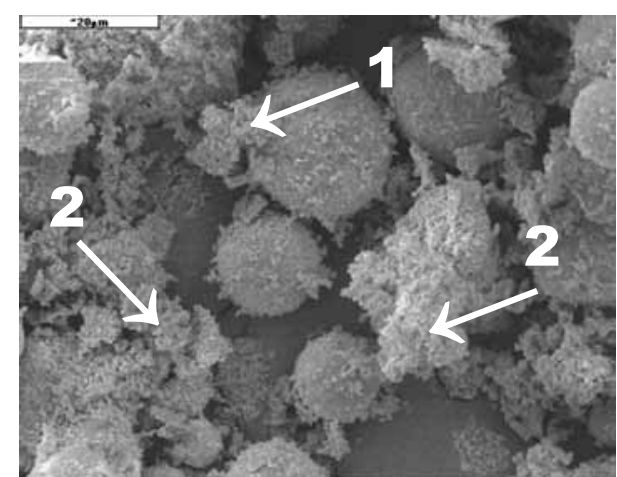

Fig. 5. Mixture of $\mathrm{NiCrBSi}$ and $\mathrm{Fe}_{2} \mathrm{O}_{3}$ powders

Rys. 5. Mieszanina proszków NiCrBSi i $\mathrm{Fe}_{2} \mathrm{O}_{3}$

$-30+7.5 \mathrm{~mm}$. Completely different responses were reported for cumulated distribution and density distribution of the $\mathrm{Fe}_{2} \mathrm{O}_{3}$ powder (Fig. 4b). The particle size distribution ranges from $0.9 \mathrm{~mm}$ up to $73 \mathrm{~mm}$, yet the particles smaller than $0.9 \mathrm{~mm}$ constitute $24.24 \%$ of the powder. The tangent of the slope of the cumulated distribution curve, $\mathrm{n}=0.5$, testifies to a wide range of particle size distribution. A sudden decline is observed in the cumulated distribution curve for particles $2.6 \mathrm{~mm}$ in size, which constitute more than $60 \%$ of the powder. Another $40 \%$ covers the range from $2.6 \mathrm{~mm}$ to $73 \mathrm{~mm}$.

The NiCrBSi and $11.5 \% \mathrm{Fe}_{2} \mathrm{O}_{3}$ powders were mechanically blended for 1 hour in a $\mathrm{V}$ type blender before deposition. The experiments showed that the ball-shaped particles of the NiCrBSi powder were completely surrounded by finer $\mathrm{Fe}_{2} \mathrm{O}_{3}$ powder particles (Fig. 5, arrow marked 1). Some of these fine $\mathrm{Fe}_{2} \mathrm{O}_{3}$ particles, however, bonded to form bigger ones (Fig. 5, arrow marked 2). The adhesion of an $\mathrm{Fe}_{2} \mathrm{O}_{3}$ particle to ballshaped NiCrBSi ones makes the transport of the spray mixture considerably easier, as there is hardly any contact with the channel surface on the way from the powder feeder to the gun.

\section{Coating characterization}

Plasma sprayed $\mathrm{NiCrBSi}+11.5 \%$ wt. $\mathrm{Fe}_{2} \mathrm{O}_{3}$ composite coatings have visible oxide strips between the highly deformed lamellae (the dark phases in Fig. 6a), as is the case of alloy powder spray coatings containing no iron oxide. The linear analysis (Fig. 6c) showed that the amount of iron and oxygen in the coatings had increased while the amount of the other constituents had decreased. The dark phase is identified with iron oxide. An increased amount of iron and oxygen can be observed also in the thin oxide films, which testifies that iron oxide is predominant there. The local analysis of this phase shows that there is a great number of peaks of iron and oxygen. The other alloying constituents are present in the dark phase, yet the number of their peaks is negligible. The local analysis of the white phase, on the other hand, shows an increased amount of nickel and the other
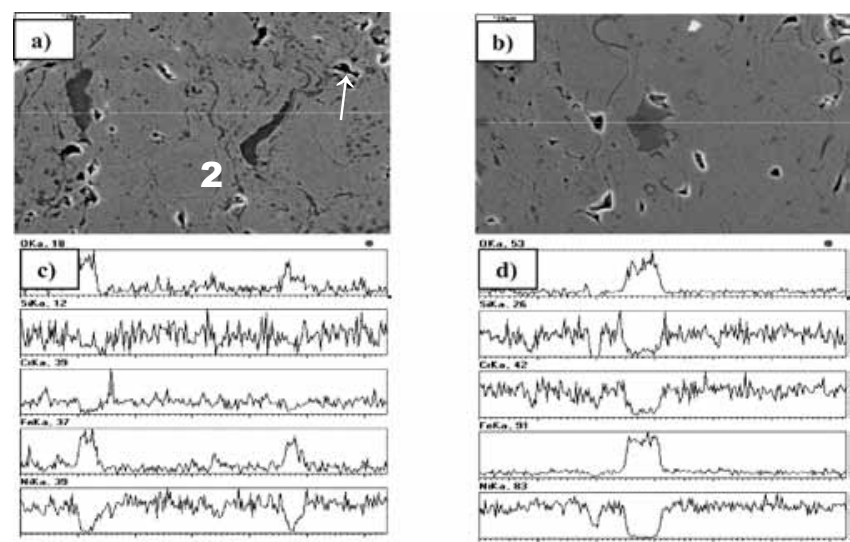

Fig. 6. Microstructure of: a) plasma sprayed $\mathrm{NiCrBSi}+11.5 \%$ wt. $\mathrm{Fe}_{2} \mathrm{O}_{3}$ coating, b) HVOF sprayed $\mathrm{NiCrBSi}+11.5 \%$ wt. $\mathrm{Fe}_{2} \mathrm{O}_{3}$ coating, c) linear analysis of plasma sprayed $\mathrm{NiCrBSi}+11.5 \%$ wt. $\mathrm{Fe}_{2} \mathrm{O}_{3}$ coating, d) linear analysis HVOF sprayed NiCrBSi $+11.5 \%$ wt. $\mathrm{Fe}_{2} \mathrm{O}_{3}$ coating

Rys. 6. Mikrostruktura: a) powłoka natryskiwana plazmowo: $\mathrm{NiCrBSi}$ $+11,5 \%$ wag. $\mathrm{Fe}_{2} \mathrm{O}_{3}$ b) powłoka natryskiwana HVOF: $\mathrm{NiCrBSi}+11,5 \%$ wag. $\mathrm{Fe}_{2} \mathrm{O}_{3}, \mathrm{c}$ ) rozkład liniowy pierwiastków w powłoce natryskiwanej plazmowo: $\mathrm{NiCrBSi}+11,5 \%$ wag. $\mathrm{Fe}_{2} \mathrm{O}_{3}$, d) rozkład liniowy pierwiastków w powłoce natryskiwanej HVOF: $\mathrm{NiCrBSi}+11,5 \%$ wag. $\mathrm{Fe}_{2} \mathrm{O}_{3}$

constituents of the NiCrBSi powder. Studying the coating images and their chemical composition, one can easily discover that by plasma spraying of the $\mathrm{NiCrBSi}+11.5 \%$ wt. $\mathrm{Fe}_{2} \mathrm{O}_{3}$ mixture we obtain a composite coating. The matrix produced by spraying metallic powder contains iron oxide occurring in the form of lamellae, which vary in height. HVOF $\mathrm{NiCrBSi}+11 . \%$ wt. $\mathrm{Fe}_{2} \mathrm{O}_{3}$ composite coatings have hardly visible short oxide strips between slightly deformed lamellae (Fig. 6b), as is the case of spraying of pure alloy powder. Between the lamellae we report a large area of the dark phase. The linear analysis shows (Fig. 6d) that there is a considerable increase in the amount of iron and oxygen, and, at the same time, a significant decrease in the amount of nickel, chromium and silicon. From that analysis as well as a local analysis it is clear that this is iron oxide. The dark phase on the left, however, shows no increase in the amount of iron or oxygen, yet there is a considerable decrease in the amount of the other constituents of the NiCrBSi powder. The changes in the component intensity confirm the occurrence of pores. The local analysis of the white phase proves a greater intensity of the peaks of nickel than in the case of a plasma sprayed coating. The changes in the element level are less varied, which is illustrated by iron. This implies less intensive phase transitions of the NiCrBSi powder during the HVOF spray process. Due to high particle velocity and different particle sizes, the $\mathrm{Fe}_{2} \mathrm{O}_{3}$ content in an HVOF coating can be lower than that in a plasma sprayed coating.

\section{Phase Composition}

The phase composition of the $\mathrm{NiCrBSi}, \mathrm{Fe}_{2} \mathrm{O}_{3}$, and $\mathrm{NiCrBSi}+11.5 \%$ wt. $\mathrm{Fe}_{2} \mathrm{O}_{3}$ powders and of the coatings produced from them was thoroughly analyzed in order 
to identify all the changes and differences resulting from the applied thermal spray process (Figs. $7 \div 9$ ). The fundamental phase in the $\mathrm{NiCrBSi}$ powder (Fig. 7a) and the NiCrBSi thermal spray coatings was nickel, due to high nickel content, i.e. $70.51 \%$. After identifying displaced high-angle diffraction lines, one can assume that they are represented by the nickel lattice based solid solution phase. The other components include hard crystals of borides and silicates, of which only the Ni2B phase is present in all the coatings. These phases impart good wear resistance properties of the coatings. In the case of plasma sprayed NiCrBSi coatings (Fig. 7b), the Cr3Si and CrB phases were not identified. Starting powder possesses $3.4 \%$ of iron, so presence of $\mathrm{Fe}_{2} \mathrm{O}_{3}$ results from its oxidation in the plasma stream. HVOF sprayed NiCrBSi coatings (Fig. 7c) showed no changes in the phase composition compa-
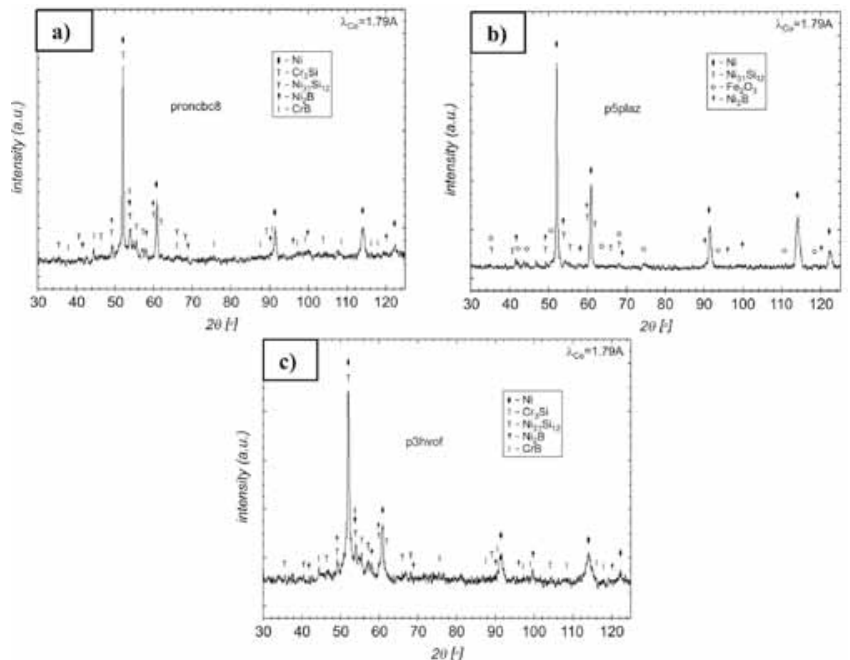

Fig. 7. Diffractogram of NiCrBSi: a) powder, b) plasma sprayed coating, b) HVOF sprayed coating

Rys. 7. Rozkład pierwiastków chemicznych w NiCrBSi: a) proszek, b) powłoka natryskiwana plazmowo, c) powłoka natryskiwana HVOF
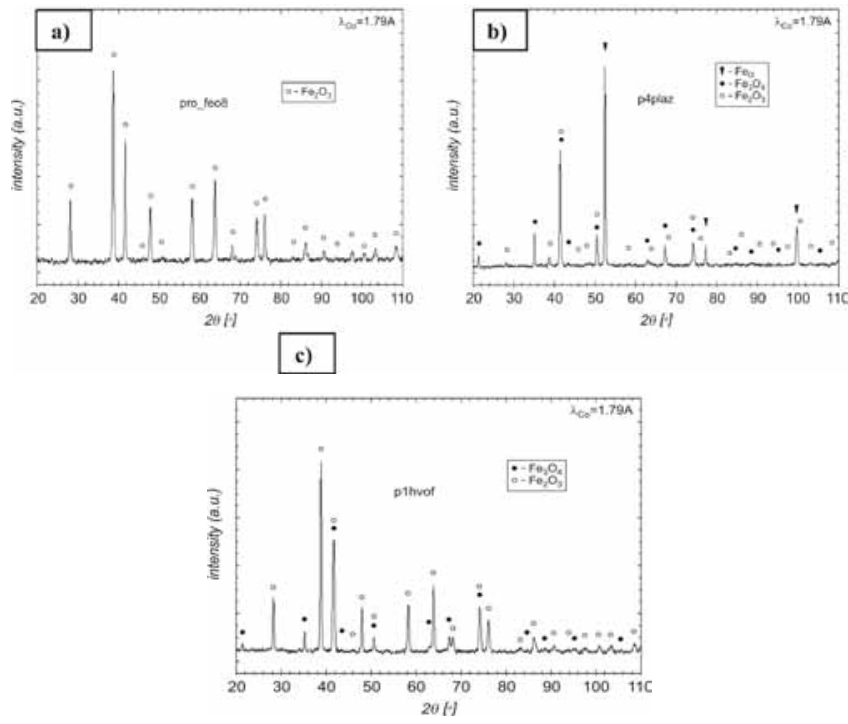

Fig. 8. Diffractogram of $\mathrm{Fe}_{2} \mathrm{O}_{3}$ : a) powder, b) plasma sprayed coating, b) HVOF sprayed coating

Rys. 8. Rozkład pierwiastków chemicznych w $\mathrm{Fe}_{2} \mathrm{O}_{3}$ : a) proszek, b) powłoka natryskiwana plazmowo, c) powłoka natryskiwana HVOF red with that of the feedstock powder. Identical types of phases and negligible changes in their relative contents were reported in both diffraction patterns. This results from a low temperature of the HVOF stream and a short powder dwell time. The influence of temperature on the phase composition of the coating material is most visible for $\mathrm{Fe}_{2} \mathrm{O}_{3}$, which was identified as hematite (Fig. 8a). From a considerable difference in the intensity of all the peaks of hematite in the powder and the deposited coatings it is clear that, in the spray stream, the hematite is transformed into magnetite, with the latter not being present in the powder material. Since the peaks of hematite are very low, its presence in the plasma sprayed coating is found to be low (Fig. 8b). The presence of iron peaks is attributable to the decomposition of magnetite in the plasma stream to form iron and oxygen. A lower temperature of the HVOF stream causes only a partial transformation of hematite into magnetite. The number of magnetite peaks in an HVOF coating is much smaller than that in a plasma sprayed coating, thus it can be concluded that its content is very low (Fig. 8c). A phase analysis was carried out twice to find iron oxides in the plasma-sprayed composite coatings (Figs. 9a and b). The plasma- and HVOF sprayed $\mathrm{NiCrBSi}+11.5 \%$ wt. $\mathrm{Fe}_{2} \mathrm{O}_{3}$ coatings (Fig. 9c) had only one phase common, i.e. $\mathrm{Ni}_{2} \mathrm{~B}$, which was present in all the analyzed coatings and the feedstock powder. The $\mathrm{Fe}_{2} \mathrm{~B}$ phase in the plasma sprayed composite coating is a result of the reaction of boron with iron from iron oxide. The other phases present in both types of coatings are $\mathrm{Fe}_{2} \mathrm{O}_{3}$ and $\mathrm{Cr}_{5} \mathrm{~B}_{3}$. $\mathrm{Fe}_{3} \mathrm{O}_{4}$, which is present in both plasma and HVOF sprayed $\mathrm{Fe}_{2} \mathrm{O}_{3}$ coatings, is absent in the composite coatings. The plasma composite coating contains new phases, i.e. $\mathrm{Cr}_{3} \mathrm{Si}, \mathrm{CrB}_{2}, \mathrm{Ni} 16 \mathrm{Cr}$ $6 \mathrm{Si} 7$ and $\mathrm{Ni}_{2} \mathrm{O}_{3}$. The new boride and silicate phases in the HVOF sprayed composite coatings are $\mathrm{CrB}, \mathrm{B}_{4} \mathrm{Si}$ and $\mathrm{Ni}_{3} \mathrm{Si}$.

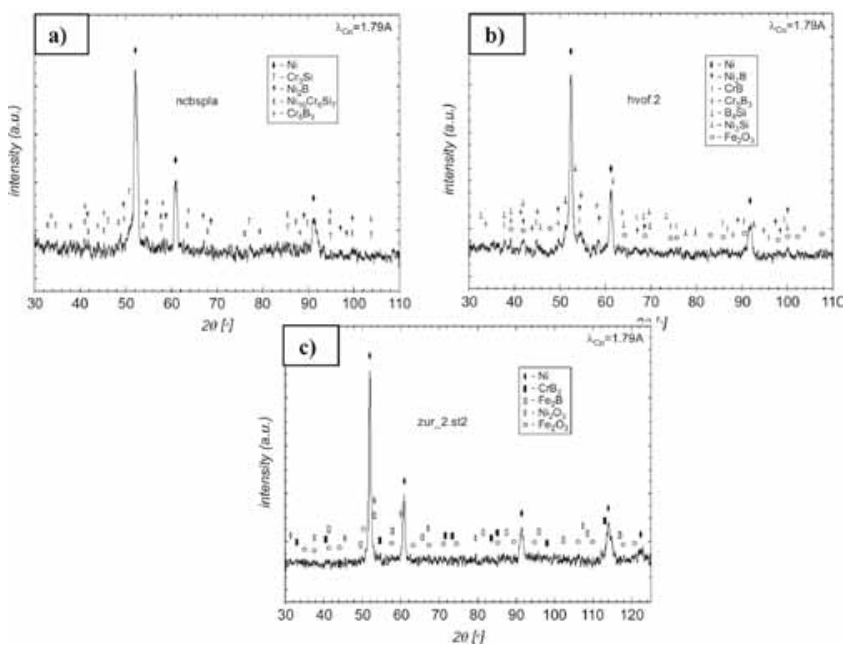

Fig. 9. Diffractogram of $\mathrm{NiCrBSi}+11.5 \%$ wt. $\mathrm{Fe}_{2} \mathrm{O}_{3}$ : a) plasma sprayed coating $(A)$, b) plasma sprayed coating $(B)$, c) HVOF sprayed coating

Rys. 9. Rozkład pierwiastków chemicznych w NiCrBSi $+11,5 \%$ wag. $\mathrm{Fe}_{2} \mathrm{O}_{3}$ : a) powłoka natryskiwana plazmowo (A), b) powłoka natryskiwana plazmowo (B) b) powłoka natryskiwana HVOF 


\section{Results of tribological tests}

Wear tests of $\mathrm{NiCrBSi} / \mathrm{Fe}_{2} \mathrm{O}_{3}$ composite coatings revealed lower loss of mass for HVOF sprayed coatings than for plasma sprayed. On the base of carried out investigations, it can be concluded that $\mathrm{Fe}_{2} \mathrm{O}_{3}$ addition cause increasing wear of plasma and HVOF sprayed NiCrBSi coatings. Results obtained on the base of investigations with Falex tester showed that plasma sprayed coatings possessed higher scuffing resistance than HVOF sprayed. Significant standard deviations of tests results come from heterogeneous morphology of sprayed coatings and testify about low repeatability of processes

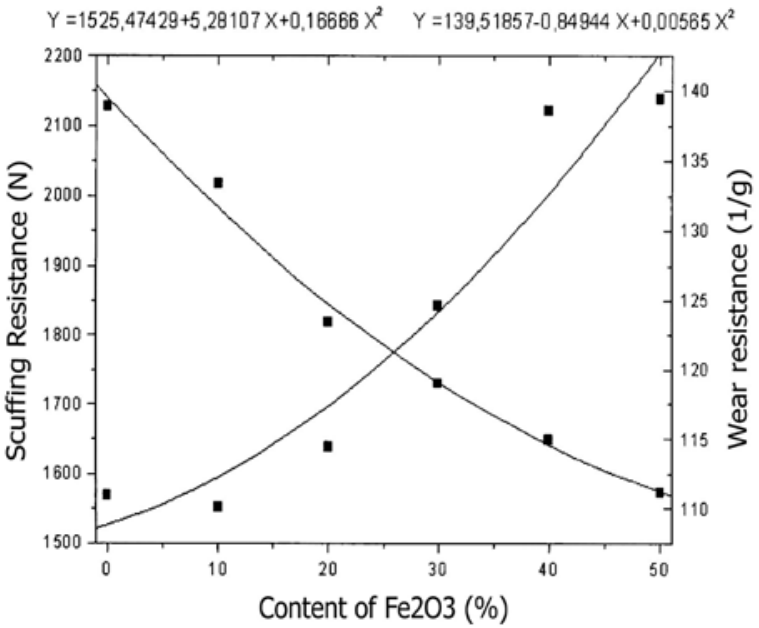

Fig. 10. Wear and scuffing resistance of plasma sprayed composite coating with different percentage of $\mathrm{Fe}_{2} \mathrm{O}_{3}$ in the mixture

Fig. 10. Odporność na ścieranie natryskiwanych plazmowo powłok kompozytowych o różnym udziale wagowym $\mathrm{Fe}_{2} \mathrm{O}_{3}$ occurring during scuffing phenomena. Results of carried out wear and scuffing resistance tests showed that addition of $\mathrm{Fe}_{2} \mathrm{O}_{3}$ powder to the NiCrBSi matrix influenced for wear and friction processes of plasma and HVOF sprayed composite coatings. Fig. 10 and Fig. 11 present results of carried out investigations of wear and scuffing resistance of sprayed coatings (approximation by quadratic equation) as function of $\mathrm{Fe}_{2} \mathrm{O}_{3}$ content in mixture with $\mathrm{NiCrBSi}$ powder. On the base of obtained results it can be claim that $26 \%$ addition of $\mathrm{Fe}_{2} \mathrm{O}_{3}$ in mixture for plasma spraying and $22,5 \%$ addition of $\mathrm{Fe}_{2} \mathrm{O}_{3}$ in mixture for HVOF spraying allow to receive coatings with optimum wear and scuffing resistance.

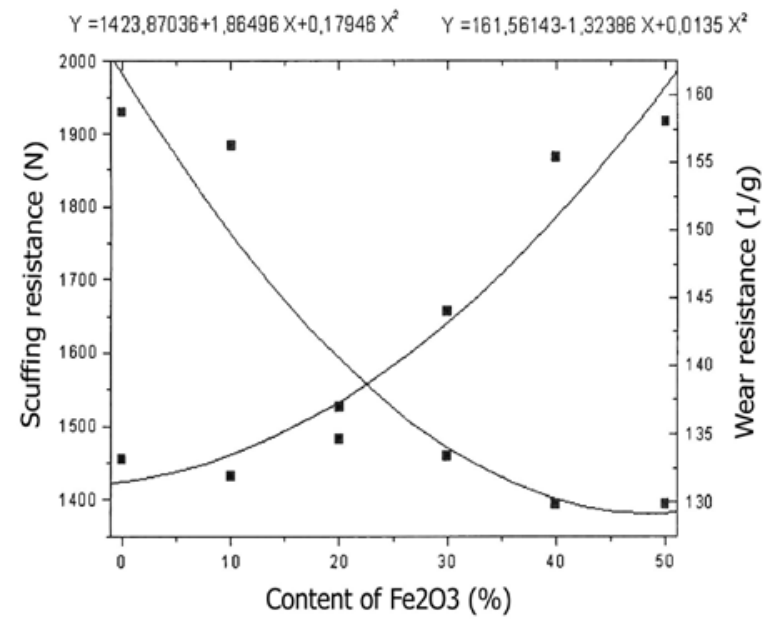

Fig. 11. Wear and scuffing resistance of HVOF sprayed composite coating with different percentage of $\mathrm{Fe}_{2} \mathrm{O}_{3}$ in the mixture

Fig. 11. Odporność na ścieranie natryskiwanych HVOF powłok kompozytowych o różnym udziale wagowym $\mathrm{Fe}_{2} \mathrm{O}_{3}$

\section{Conclusions}

Plasma and HVOF sprayed NiCrBSi/ $\mathrm{Fe}_{2} \mathrm{O}_{3}$ composite coating containing solid lubricant were successfully deposited despite significant differences in particle size distribution of feedstock powders. The phase compositions of the powder feedstock and plasma and HVOF composite coatings were determined by means of $\mathrm{X}$-ray diffraction analysis. The main phase in the NiCrBSi powder and coatings was nickel, which was due to a high nickel content in the feedstock powder. The other phases include hard crystals of different borides and silicates, of which only the $\mathrm{Ni}_{2} \mathrm{~B}$ phase is present in all the sprayed coatings. HVOF sprayed NiCrBSi coatings showed no changes in the phase due to low temperature of the HVOF stream and its limited influence on the NiCrBSi powder. The new $\mathrm{Fe}_{3} \mathrm{O}_{4}$ phase appears in the coatings produced from $\mathrm{Fe}_{2} \mathrm{O}_{3}$ powder, which contains only hematite. There are considerable differences in the intensity of $\mathrm{Fe}_{2} \mathrm{O}_{3}$ and $\mathrm{Fe}_{3} \mathrm{O}_{4}$ peaks in the plasma and HVOF sprayed coatings. The plasma stream causes transformation of hematite into magnetite; in the case of HVOF stream, such transformations are significantly smaller. In both plasma and HVOF sprayed $\mathrm{NiCrBSi}+11.5 \%$ wt. $\mathrm{Fe}_{2} \mathrm{O}_{3}$ coatings new phases were detected. The plasma composite coating contains $\mathrm{Cr}_{3} \mathrm{Si}, \mathrm{CrB}_{2}, \mathrm{Ni}_{16} \mathrm{Cr}_{6} \mathrm{Si}_{7}$ and $\mathrm{Ni}_{2} \mathrm{O}_{3}$. In HVOF sprayed composite coatings we have the $\mathrm{CrB}, \mathrm{B}_{4} \mathrm{Si}$ and $\mathrm{Ni}_{3} \mathrm{Si}$ phases. Studies of the coatings wear and scuffing resistance showed that an optimal content of $\mathrm{Fe}_{2} \mathrm{O}_{3}$ is about $26 \%$ for plasma sprayed coatings and $22,5 \%$ for HVOF deposited coatings. 